\title{
LEGAL REGULATION ISSUES OF OBTAINING ORGANS AND TISSUES FOR TRANSPLANTATION
}

D0I: 10.36740/WLek202012239

\author{
Semen G. Stetsenko ${ }^{1}$, Valentina Yu. Stetsenko ${ }^{2}$, Yurii 0. Buhlak ${ }^{3}$ \\ 'SUPREME COURT, KYIV, UKRAINE \\ ${ }^{2}$ NATIONAL PEDAGOGICAL UNIVERSITY M.P. DRAHOMANOV, KYIV, UKRAINE \\ ${ }^{3}$ DONETSK LAW INSTITUTE OF THE MINISTRY OF INTERNAL AFFAIRS OF UKRAINE, KRYVYI RIH, UKRAINE
}

\begin{abstract}
The aim: To analyze the views of scientists and practitioners on the legal regulation of organ and tissue transplantation, as well as analyze the factors that affect the activity of clinical transplantation.

Materials and methods: The materials for this study were scientific publications and statistics. Methods of analysis, synthesis, observation and generalization were used in the process of this research.

Conclusions: Legal professionals generally adhere to the principle of the priority of human rights over expediency, while health professionals allow the removal of the transplant from the body of the deceased without her lifetime consent. The activity of clinical transplantation is influenced by the following factors.by many different factors: detailed legal regulations; availability of a well-organized system of transplantology, specially trained teams; the existence of a presumption of consent to the removal of organs and tissues after death; the attitude of society to transplantology.
\end{abstract}

KEY WORDS: Transplantation, deceased donation, living donation, presumed consent

Wiad Lek. 2020;73(12 p. II):2940-2945

\section{INTRODUCTION}

Although most countries in the world are continually trying to increase the number of transplant operations, only a few are able to achieve the desired results. The growing list of patients waiting for the necessary transplant and the constant lack of donor organs prompt politicians, scientists, and practitioners to seek new approaches to address this issue.

\section{THE AIM}

To analyze the views of scientists and practitioners on the legal regulation of organ and tissue transplantation, as well as analyze the factors that affect the activity of clinical transplantation.

\section{MATERIALS AND METHODS}

The materials for this study were scientific publications and statistics. Methods of analysis, synthesis, observation and generalization were used in the process of this research.

\section{REVIEW AND DISCUSSION}

The active development of science has stimulated the emergence of new activities that pose a challenging task for society. One of such new directions of medical activity is transplan- tology. "With its development (V.P. Salnikov, S.G. Stetsenko. Transplantation of human organs and tissues: problems of legal regulation. 2000) clinical transplantology raised a few moral, ethical and legal issues. The resolution of the first two is connected with the purposeful activity of representatives of various spheres of social life. Lawyers' task is to develop effective, based on the real needs of practical transplantology, mechanisms for the legal regulation of organ and tissue transplantation. World experience shows that in countries where the legal regulation of transplantation is of great importance, the success of transplants is more obvious "[1].

The existence of transplantation at the current stage, when therapeutic cloning and artificial cultivation of necessary organs and tissues are still underdeveloped, is possible only based on the necessary donor material obtained from living or dead persons. Today, this is the core of all transplantology, and the development of transplantology in a country largely depends on proper legal regulation of the procedure for obtaining donor material.

Transplantation using living donors, usually, is quite clearly regulated in the legislation of the countries and has no fundamental issues. A surgical intervention aimed at removing the graft for subsequent transplantation is, of course, possible if the following conditions are met: genetic affinity with the recipient or the existence of close social ties; voluntary informed, competent consent of the donor; the age of the donor; the absence of disease transmitted by transplantation of donor material. 
From a legal perspective, the issue that needs to be most carefully regulated in transplantation using living donors is the issue of obtaining their informed consent to remove the necessary transplants. Of course, the principle of priority of the interests of a living donor applies here. The donor's consent is based, first, on the receipt of complete, objective and comprehensive information about future intervention and its possible complications, the degree of risk. Moreover, the information should be provided in an accessible and understandable manner, considering the fact that a potential donor may not have sufficient knowledge in the field of medicine.

Another necessary component of a living donor's consent is its voluntariness, i.e. decision-making in the absence of psychological, physical influence, and any other external factors that would indicate the involuntary nature of such consent. The word "voluntary" (H.Ya. Lopatenkov. Patient's rights. 2005) emphasizes that this decision cannot be the result of external coercion or the result of the active persuasion of anyone (even a doctor) in need for a specific course of action. It should not be the result of the active influence of another person's will but should only result from personal choice based on complete information on the issue [2].

According to the Global Observatory on Donation and Transplantation (GODT), which works with the WHO, most transplants are made from organs and tissues obtained from the dead persons. For example, in 2018, of the 95,479 kidney transplants performed worldwide, only $36.2 \%$ were from living donors; of 34074 liver transplants - 19.2\% were from living donors [3]. Besides, most organs can only be obtained from a deceased person. Therefore, the most pressing issue is the legal regulation of transplantation using donor material from a deceased person.

Among the critical aspects of post-mortem donation is obtaining a person's lifetime consent to a graft removal after death. The most serious (Grishchenko V. Ethical issues of cell and tissue transplantation. 2002) of its aspect is associated with the receipt of organs and tissues for transplantation, which requires compliance with all principles of medical ethics and legal regulation [4]. It is essential to determine the role of the deceased's will regarding the possibility of removing organs and tissues that he/she expressed during life. And here the countries do not have a common opinion. There are three modern systems of posthumous organ donation:

\section{1 . Presumption of consent.}

That means that organ donation is automatically considered possible for patients diagnosed with brain death unless they have specifically registered their lifelong refusal to sacrifice themselves for transplantation. However, in some countries, despite legal permission, doctors still ask permission from relatives.

\section{Informed consent.}

It is a voluntary system of organ donation, according to which relatives give permission at the time of a potential donor's death, usually knowing that the potential donor has expressed a desire to become a donor.

\section{Required request.}

In the United States, physicians responsible for potential donors should ensure that someone communicate with their family about organ donation.
In the scientific literature, the presumed consent, i.e. the presumption of consent to the removal of organs or tissues from a corpse for transplantation, is defined (S.H. Stetsenko, O.H. Pelagesha Medical Law of Ukraine (legal principles of transplantation of human organs and tissues). 2014) as a legal order, according to which representatives of a medical institution are allowed to remove organs or tissues from a deceased person for further transplantation if during their lifetime the person or his relatives after death did not declare in a certain way their consent to the removal of organs or tissues. In other words, if during the life of the person or after his death, relatives have not stated that they are disagree - then their consent is presumed (presumption of the consent) to remove the grafts for further transplantation [6].

While informed consent, i.e. the presumption of disagreement with the removal of organs or tissues from a corpse for transplantation, is a legal order (S.H. Stetsenko, O.H. Pelagesha Medical law of Ukraine (legal principles of transplantation of human organs and tissues). 2014), according to which representatives of a medical institution are prohibited from removing organs or tissues from a deceased person for further transplantation if there is no evidence of written consent to become a donor of anatomical materials for transplantation or no evidence of such consent from relatives of the deceased. In other words, in order to be able to remove organs or tissues, medical staff must have the written consent of the deceased, which she gave during life, or the consent of the relatives of the deceased [6].

There is also no consensus among scientists and experts dealing with transplantation regarding the need to introduce a particular system of posthumous donation. In the legal literature (I.A. Ivannikov. Medical law.2008), there is no consensus on the legal validity of the presumption of consent. Its supporters refer to the priority of a living person's interests over the deceased, and opponents of the presumption point to its inconsistency with the advantages of choice, expression of will [7].

For example, D.Yu. Karkavina (D.Yu. Karkavina. The patient's table book, or How to protect your rights when seeking medical care. 2007) considers the presumption of consent as a means that is fully justified in order to save human life, the treatment of which is already found in medicine (unlike man - a potential source of donor organs, which cannot be cured at the current level of medical development) [8]. According to A.A. Zhalinskaiia (A.A. Zhalinskaiia Discussions on the legislation on transplantation in Germany. 1998.), one who wants to protect their right to inviolability after a death must act by active expression of will [9].

Opponents of the presumption of consent believe that this is a violation of a number of human rights, the lack of due respect for the individual's rights after death. N.V. Putilo (N.V. Putilo. Commentary on the Fundamentals of the legislation of the Russian Federation on public health. 2003.) indicates that the presumption of disagreement would more logically and consistently protect the interests of relatives of the deceased, the inviolability of the body of the deceased [10]. H.N. Krasnovskii (Krasnovskii H.N. Bioethical and criminal problems in the Law of the Russian Federation "On transplantation of organs and (or) human tissues." 1993) indicates that, above 


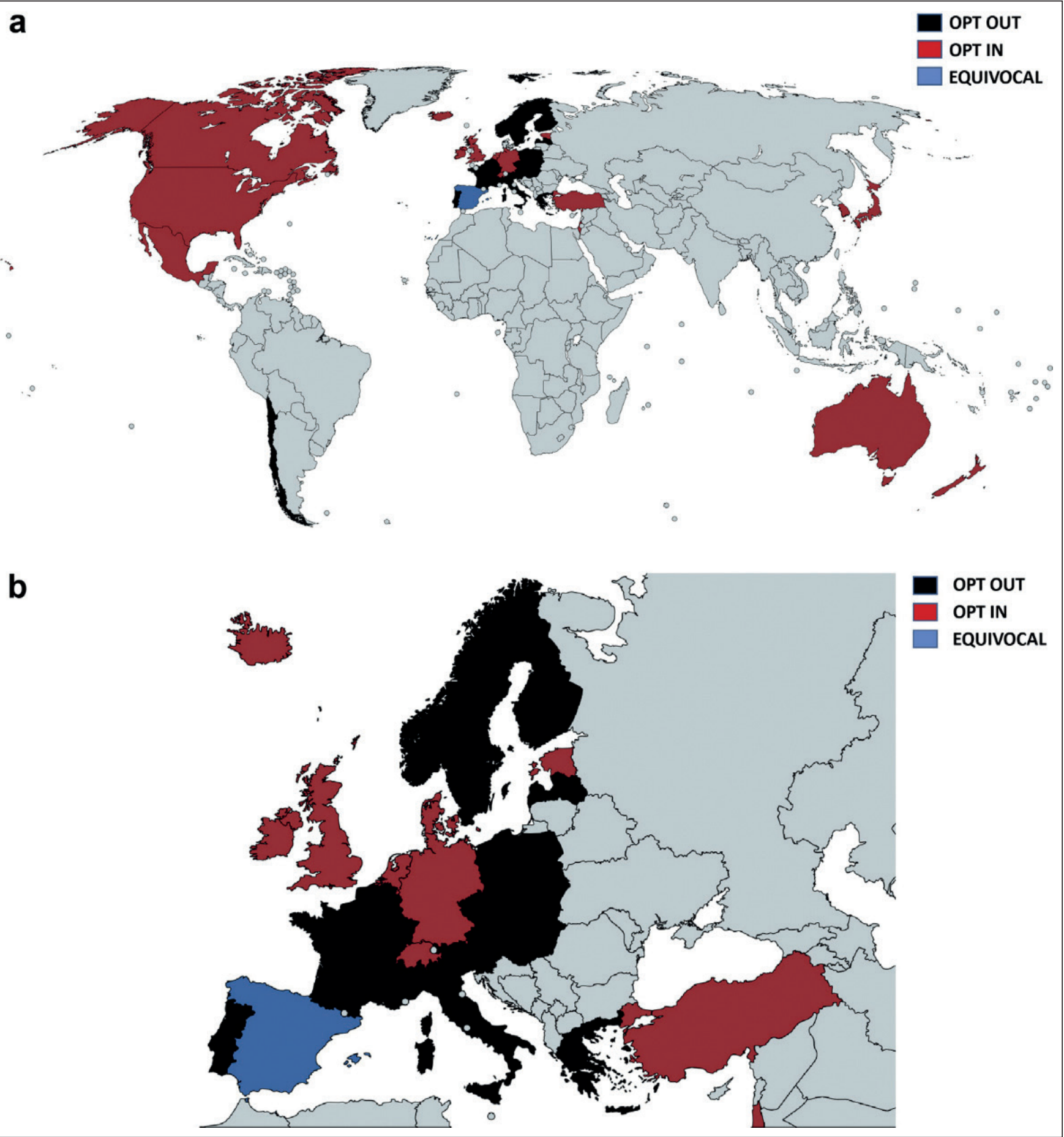

Fig. 1. Distribution of countries of the Organisation for Economic Co-operation and Development by presence / absence of presumed consent Source: Adam Arshad, Benjamin Anderson and Adnan Sharif. Comparison of organ donation and transplantation rates between opt-out and opt-in systems. Clinical Investigation. 2019; vol. 95, issue 6: 1453. doi:https://doi.org/10.1016/j.kint.2019.01.036

all, human rights are ignored, in particular, the donor's one, who certainly during his/her life must adequately address the issue of the possibility of using his/her organs or tissues for transplantation after death, i.e. the legislator does not recognize the priority of donor rights [11].

Specialists in medicine are more categorical about the legality of removing organs and tissues from the dead. Thus, the famous cardiac surgeon Yu. L. Shevchenko notes: "Have you ever thought about how many human organs, including hearts, are thrown into the morgue every day? After all, healthy organs could save someone"[12]. Ukrainian specialist V. Saenko claims that " $50-60$ people die in an ambulance in a year alone. That means that at least 35-40 hearts and 100-120 kidneys can be transplanted. And we get just a few units "[13]. "If to be guided by the presumption of disagreement, there will be no transplantology," - says N.A. Tomilina, nephrologist [14]. 
WORLDWIDE ACTUAL DECEASED ORGAN DONORS RATE 2019 (pmp)

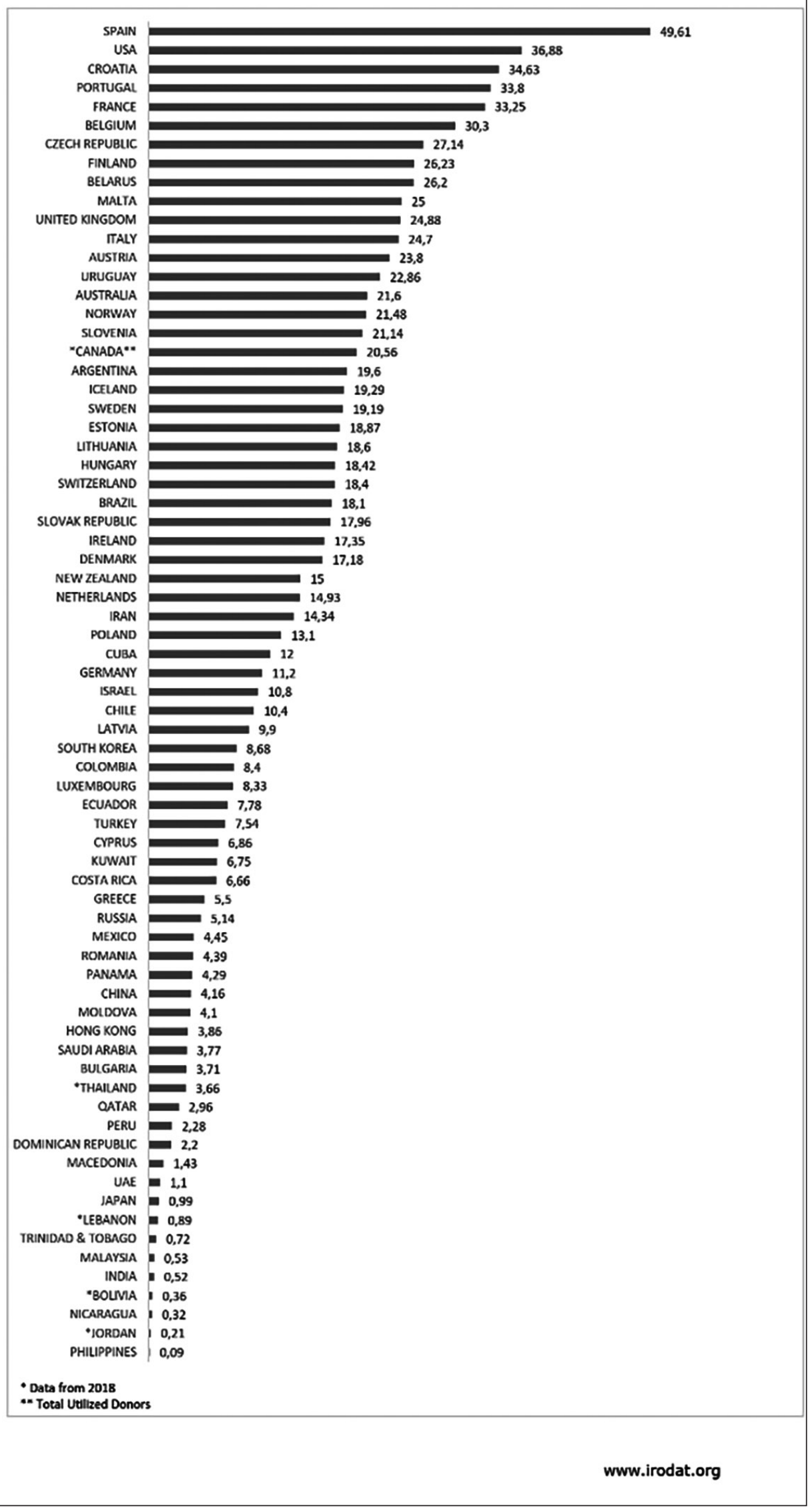

Fig. II. Statistical International Registry in Organ Donation and Transplantation (IRODaT) 2019. 
The supporters of the presumption of consent's main argument is that otherwise, the development of clinical transplantation is significantly inhibited. But this seems to be a very ambiguous question.

Thus, researchers Adam Arshad, Benjamin Anderson and Adnan Sharif in 2019 analyzed 35 countries registered in the Organization for Economic Cooperation and Development. Among these countries, 17 have a statutory presumption of opt-out and 18 have a presumption of opt-in. Indicators of organ donation and transplantation were obtained for 2016 from the Global Observatory for Donation and Transplantation. The distribution of the countries analyzed by the authors is given in Figure 1. Spain is listed separately, as in the presence of a legally defined presumption of consent, relatives are still asked for consent to remove organs and tissues from the deceased.

The study (Adam Arshad, Benjamin Anderson and Adnan Sharif. Comparison of organ donation and transplantation rates between opt-out and opt-in systems. 2019.) found that there is no significant benefit for countries that currently have a presumption of disagreement and which are considering the possibility of moving to the presumption of consent. Although historically in some of the countries analyzed, there has been a significant increase since the introduction of the presumption of consent, such as Belgium. Other countries showed worse results, i.e., there was no difference, or there was an actual drop in organ donation level, including Singapore, Brazil, Chile, Sweden, and later Wales [15].

These findings are indirectly supported by data provided by the International Registry in Organ Donation and Transplantation (IRODaT). See Tab. II. As you can see, the number of operations in 2019 (for some countries in 2018) for transplantation using organs and tissues of the deceased per million was in the US, Portugal, where there is a presumption of disagreement, 36.88 and 33.8, respectively. While in Sweden, Norway, where the presumption of consent applies, this rate is 19.19 and 21.48, respectively [16].

Spain, the country with the highest rate of post-mortem donation - 49.61 in 2019, which is much more than in any other country, recognizes the presumption of consent, but relatives are still asked every time there is a question of removing anatomical material from a deceased person. Although the presumption of consent was actually introduced in Spain in 1979, only with the introduction of the National Transplant Organization (ONT) - ten years after that - the donor donations level began to improve. Within a few years of ONT's work, Spain became the country with the highest number of organ donors per million. Spain has invested in training more than 16,000 health workers in organ donation and transplantation since the founding of ONT. And since 1992, Spain's position as a world leader has remained continuous [17].

The second illustrative example is Germany. Despite the fact that in this country (Mark Hallam, Astrid Prange. German parliament: Explicit consent is still necessary from organ donors. 2020), the level of organ donation is 11.5 donors per million people, which is almost three times lower than in the United States, and more than four times worse than that of the world leader Spain, the German Parliament on January 16, 2020, rejected the proposal of the Ministry of Health for a new sys- tem of organ donation. Due to the low number of donors, the Minister of Health wanted to have a system of presumption of consent, relying on people who refuse to make donations. Thus, the rules of organ donation in Germany will remain mostly unchanged. The country will adhere to a system of informed consent, according to which only people who voluntarily register as organ donors have the right to participate in posthumous donation. However, in an attempt to reduce German waiting lists for transplants, when renewing national cards, people will be asked if they want to donate organs [18].

The low level of transplants with the use of deceased donors in Germany is justified, among other things, by the lack, in contrast to Spain, a well-organized system in this area. In Germany (Fabian Becker, Keith J. Roberts, [...], and Harald H. Schrem. Optimizing Organ Donation: Expert Opinion from Austria, Germany, Spain and the UK 2020) "donor evaluation is almost exclusively organized and coordinated by intensive care therapy physicians, while DSO transplant coordinators are rarely consulted. In recent years, the assessment of potential organ donors has been seen as an increasing workload of intensive care physicians from all four countries and all German experts ... All experts from Germany reported in this study an overload of resuscitation doctors, a lack of qualified staff, and a lack of experienced consultants who take responsibility and help doctors identify and evaluate potential organ donors. This may, at least in part, explain the decline in organ donation due to shortcomings in the recognition and accounting of potential organ donors." [19].

Eric Johnson and Dan Goldstein conducted an interesting online experiment in 2003, asking people if they wanted to be donors. Some people were told that they were not organ donor by default and were given the opportunity to confirm or change their default status. Others were told that they should be donors to the body by default and were again given the opportunity to confirm or change this status. When participants had to choose to become an organ donor (i.e. agree to a potential donation), only $42 \%$ did so. However, when they had to abandon, $82 \%$ agreed to be donors.

How many of you have changed your default mobile phone settings? This force can be used to change behavior. Setting default options can significantly impact results, from increasing donor organs to increasing personal savings to better investment. Never underestimate the force of inertia [20].

Thus, we fully agree with the researchers, who believe that "the most critical issue that is not expected to be resolved is the apathetic attitude and behavior of the public regarding organ donation. The gap between the desire for organ transplantation (if ever needed) and the simultaneous reluctance to donate organs (if possible) simply will not change with the transition to the presumption of consent... Changing attitudes is a crucial factor, and new strategies to change this need to be considered. For example, Israel has introduced a system of organ allocation priorities for registered donors, and initial results have shown a significant increase in both the level of consent and actual organ donation [19]. Although some scientists believe that therapeutic organ and tissue cloning based on genetic technology is the best way out and solving ethical transplantation problems [21]. 


\section{CONCLUSIONS}

The views of scientists and practitioners on the legal regulation of organ and tissue transplantation are differing widely. Legal professionals generally adhere to the principle of the priority of human rights over expediency, while health professionals who are directly involved in clinical transplantation have a more categorical view, especially regarding posthumous donation, and concede the removal of the transplant from the body of the deceased without her lifetime consent.

The activity of clinical transplantation is influenced by many different factors. It is not possible to single out certain factors as the main ones. However, it seems that an important role is played by: detailed legal regulations; availability of a well-organized system of transplantology, specially trained teams; the existence of a presumption of consent to the removal of organs and tissues after death; the attitude of society to transplantology.

\section{REFERENCES}

1. Sal'nikov V.P., Stecenko S.G. Transplantaciya organov i tkanej cheloveka: problemi pravovogo regulyuvannya. [Transplantation of human organs and tissues: problems of legal regulation] Fond «Universitet»;2000, p. 102. (Ru).

2. Lopatenkov G. YA. Prava pacienta. Prakticheskie rekomendacii. [Patient rights. Practical advice] SPb.: BHV-Peterburg; 2005, p. 98. (Ru).

3. The Global Observatory on Donation and Transplantation Available from: http://www.transplant-observatory.org/ [reviewed 2020.08.12].

4. Hryshchenko V. Etychni pytannia klitynnoi i tkanynnoi transplantatsii. [Ethical issues of cell and tissue transplantation] Visnyk NAN Ukrainy.2002, 1: 30. (Ua).

5. The Eurotransplant network Available from:https://www.eurotransplant. org/about-eurotransplant/legislation/ [reviewed 2020.08.12].

6. Stetsenko S.H., Pelahesha 0.H. Medychne pravo Ukrainy (pravovizasady transplantatsii orhaniv i tkanyn liudyny). [Medical law of Ukraine (legal bases of transplantation of human organs and tissues)] K.: Atika;2014, p.19-20. (Ua).

7. Ivannikov I.A. Medicinskoe pravo [ucheb. posob.] [Medical law: textbook] M.: Akademcentr; 2008, s. 103. (Ru).

8. Karkavina D.YU. Nastol'naya kniga pacienta, ili Kakzashchitit' svoi prava pri obrashchenii za medicinskoj pomoshch'yu. [Patient's Handbook, or How to Protect Your Rights When Seeking Medical Care] Rostov n /D.: Feniks; 2007, s.325. (Ru).

9. ZHalinskaya A.A. Diskussii po povodu zakonodatel'stva o transplantacii v FRG (Obzor). [Discussions on transplant legislation in Germany (Review)] Social'nye i gumanit. nauki. Seriya 4. Gosud. i pravo. 1998; 4:185. (Ru).

10. Putilo N.V. Kommentarij k Osnovam zakonodatel'stva RF ob ohrane zdorov'ya grazhdan. [Commentary on the Fundamentals of Legislation of the Russian Federation on Health Protection] M.: YUsticinform. 2003:165-166 (Ru).

11. Krasnovskij G.N. Bioeticheskie i ugolovno-pravovye problemy v Zakone Rossijskoj Federacii «0 transplantacii organov i (ili) tkanej cheloveka». [Bioethical and criminal-legal problems in the Law of the Russian Federation "On transplantation of human organs and (or) tissues."] Gosudarstvo i pravo.1993;12:70. (Ru).

12. Romanenko V., Nikitina V. Argumenty i fakty. [Arguments and Facts.] 1998; 18:3. (Ru).

13. Kurolenko N. SHans na zhizn'. [A chance for life.] Kievskie vedomosti. 2003; 8noyabrya:11. (Ru).
14. Kukulevich M. Pravo na zhizn'. Zametki o transplantacii organov v Rossii. [The right to live. Notes on organ transplantation in Russia.] Bol'nica. 2001;4:8. (Ru).

15. Adam Arshad, Benjamin Anderson and Adnan Sharif. Comparison of organ donation and transplantation rates between opt-out and opt-in systems. Clinical Investigation. 2019; vol. 95, issue 6: 1453-1458. doi: 10.1016/j.kint.2019.01.036

16. International Registry In Organ Donation And Transplantation (IRODaT) Available from: https://www.irodat.org/img/database/pdf/ Newsletter\%20June\%202020\%200ct.pdf [reviewed 2020.08.12].

17. Chris Baraniuk. Spain leads the world in organ donation. What's stopping other countries catching up? 06 AUG 2018. Available from: https:// mosaicscience.com/story/spain-uk-organ-donation-transplants-liverkidney-heart-lungs-surgery-nhs/. [reviewed 2020.08.12].

18. Mark Hallam, Astrid Prange. German parliament: Explicit consent still necessary from organ donors. DW News. 16.01.2020. Available from: https://www.dw.com/en/german-parliament-explicit-consent-stillnecessary-from-organ-donors/a-52022245\#: :text=German $\% 20$ parliament $\% 20$ debates\%20'opt $\% 2$ Dout,as\%20organ\%20donors\%20 are\%20eligible) [reviewed 2020.08.12].

19. Fabian Becker, Keith J. Roberts, Miriam de Nadal et al. Optimizing Organ Donation: Expert Opinion from Austria, Germany, Spain and the U.K. Annals of Transplantation. 2020; 25. doi: 10.12659/A0T.921727.

20. Anand Damani G. Why $99 \%$ of Austrians donate their organs. 2015. August. Available from: http://www.behaviouraldesign. com/2015/08/11/why-99-of-austrians-donate-their-organs/\#sthash. I6CEDSVC.XJR066bB.dpbs [reviewed 2020.08.12].

21. Vitaliy M. Pashkov, Iryna A. Golovanova, Petro P. Noha Principle of serviceability and gratuitousness in transplantation? Wiadomości Lekarskie 2016;tom LXIX;nr 3 (cz. II): 565 - 568

\section{ORCID and contributionship:}

Semen Stetsenko: 0000-0002-4350-2321 ${ }^{A, F}$

Valentina Stetsenko: 0000-0003-3650-4975 D, E

Yuriy Buglak: 0000-0002-0428-0121 A,F

\section{Conflict of interest:}

Authors declare no conflict of interest.

\section{CORRESPONDING AUTHOR Semen Stetsenko \\ Supreme Court \\ Moskovska str., apt. 8/5, Kyiv, Ukraine \\ tel: +380506911491 \\ e-mail:s_stetsenko@univer.km.ua}

Received: 27.08.2020

Accepted: 26.11 .2020

A - Work concept and design, B - Data collection and analysis, C - Responsibility for statistical analysis, D-Writing the article, $\mathbf{E}$-Critical review, $\mathbf{F}$-Final approval of the article 